\title{
Emerging viral infections of the nervous system
}

\author{
Richard T Johnson \\ Departments of Neurology, Molecular Biology and Genetics, and Neuroscience, The Johns Hopkins University School \\ of Medicine and Bloomberg School of Public Health, Baltimore, Maryland, USA
}

\begin{abstract}
New viral infections of the nervous system have been appearing with great regularity. Some result from the evolution of new agents and others from the entry of viruses into new hosts or environments. The emergence of neurovirulent enteroviruses causing a paralytic poliomyelitis syndrome and rhomboencephalitis represent the evolution of new human viruses. Most emerging viral infections represent movement of an agent into new geographic areas or across species barriers. The transport of neurovirulent strains of West Nile virus into the Western Hemisphere and the penetration of Nipah virus, a newly recognized paramyxovirus, across species barriers from bat to pig to man are examples that are highlighted in this review. The burgeoning human population and the speed and frequency of travel favor the evolution, preservation, and spread of new viral agents. Journal of NeuroVirology (2003) 9, 140-147.
\end{abstract}

Keywords: arboviruses; bat viruses; enteroviruses; neurovirulence; Nipah virus; paramyxoviruses; West Nile virus

\section{Introduction}

Emergence of interest in "new" infections can be traced back to Legionnaires' disease, toxic shock, Lyme disease, La Crosse virus encephalitis, and similar illnesses that attracted interest in the pre-acquired immunodeficiency syndrome (AIDS) era, but it was the precipitous appearance and frightening spread of the human immunodeficiency virus (HIV) that has galvanized interest in emerging diseases over the past two decades. The questions of where the agents come from, how much damage they may cause, and what final solutions will be found have became common in the popular as well as the scientific press.

This review will address only viruses that are regarded as new and that cause neurological disease. Focus will be on two viruses that have emerged as major causes of severe encephalitis within the past 5 years-West Nile virus in North America and Nipah virus in Southeast Asia.

Address correspondence to Dr. Richard T Johnson, Department of Neurology, Pathology 627, The Johns Hopkins Hospital, 600 North Wolfe Street, Baltimore, Maryland 21287, USA. E-mail: rtj@jhmi.edu

Received 7 November 2002; accepted 2 December 2002.

\section{Classes of new viruses}

Newly recovered viruses

To describe viruses such as human herpesvirus 6 (HHV6) and human T-cell lymphotropic virus 1 (HTLV-1) as emerging agents is inappropriate (Table 1). Roseola or exanthem subitum, the major disease associated with primary HHV6 infection, is a traditional illness, and encephalitis has long been a recognized complication of this common childhood exanthem. Only the identification of HHV6 is new. Similarly tropical spastic paraparesis, the major neurological disease associated with HTLV-1, was described long before the virus was recovered. The antiquity of the virus is attested by the finding of HTLV-1 sequences in pre-Columbian mummies (Li et al, 1999).

Evolution of new viruses

New viruses do evolve both by mutation and recombination. The fidelity of RNA transcription is poor compared to DNA due to the lack of proof reading enzymes, so RNA viruses can evolve at a remarkable rates. New human enteroviruses, defined by their failure to be neutralized by antibodies to previously known enteroviruses, appear periodically, sometimes with astonishingly novel diseases. 
Table 1 Emergence of "new" neurotropic virus disease

\begin{tabular}{cl}
\hline \multicolumn{1}{c}{ Mechanisms } & \multicolumn{1}{c}{ Examples } \\
\hline $\begin{array}{l}\text { Recognition of previous } \\
\text { undefined agent }\end{array}$ & Herpesvirus 6 encephalitis \\
Newly evolved agents & HAM/TSP with HTLV1 \\
& Enterovirus 70 and 71 paralytic \\
disease & \\
& Influenza with new recombinants \\
Entry of agent into new & AIDS \\
host or environment & Bovine spongiform encephalopathy \\
& Venezuelan hemorrhagic fever \\
& (Guanarito) \\
& Ebola \\
& West Nile virus encephalitis in \\
& New York \\
& Nipah virus encephalitis \\
\hline
\end{tabular}

In 1969 in Accra, Ghana, an epidemic of hemorrhagic conjunctivitis broke out abruptly and spread across Africa to India and the Far East with small outbreaks in Europe. It then subsided only to reappear in India in 1979, with subsequent spread to South America and the Carribean and a few cases in the United States. Following these two massive epidemics, only small outbreaks such as those in the middle East and Samoa have been noteworthy (Yin-Murphy, 1984; Johnson, 1994). In about 1 per 10,000 cases, a flaccid polio-like paralysis accompanied the conjunctivitis (Wadia et al, 1983). An enterovirus was recovered from eyes and throats but oddly not from fecal specimens. The clinical illness was so unique and the clinical spread so explosive that it was initially assumed this represented an animal virus that had crossed species barriers. Sequence comparisons, however, established its relationship to human enteroviruses, even though the new virus spread from eye to eye by hands or fomites (similar to the spread of adenoviruses) and spread so efficiently among crowded and impoverished populations that it appeared to outrun susceptible populations.

Also in 1969, enterovirus 71 made a less dramatic appearance in California as a common cause of hand-foot-and-mouth disease and rare cases of encephalitis. In 1971, epidemics of enterovirus 71 in Bulgaria and Hungary, however, were associated with flaccid paralysis (Chumakov et al, 1979). Then in 1997 and 1998, major epidemics of hand-foot-andmouth disease due to enterovirus 71 occurred in Taiwan, Japan, and Southeast Asia, accompanied by many deaths due to rhomboencephalitis (Lum et al, 1998; Ho et al, 1999; Huang et al, 1999). Most deaths were in children under 5 years of age, and death resulted from sudden cardiopulmonary collapse correlated with infection of medullary neurons (Lum et al, 1998).

Both enterovirus 70 and 71 cause a polio-like illness when inoculated into monkeys (Kono et al, 1973; Hasimoto and Hagiwara, 1983). Had these viruses appeared in the 1950s, we might have classified them as type 4 and 5 polioviruses, and the development of vaccines would have been greatly impeded.
Enterovirus 70 evolved with a nonenteric mode of transmission, a unique clinical presentation of hemorrhagic conjunctivitis and occasional flaccid paralysis. Enterovirus 71 maintained the usual mode of enteric spread, although the explosive outbreak on Taiwan suggested possible respiratory transmission (Ho et al, 1999). Classical enterovirus syndromes of hand-foot-and-mouth disease and herpangina were associated with the infection, and flaccid paralysis appeared as a complication in specific epidemics. In recent years, the virus in Asia appears to have acquired a unique neurovirulence with lethal localization to neurons in the pons, medulla, and spinal cord.

Viruses with multipartite genomes can reassort forming new viruses. New influenza viruses periodically appear; and the frequencies of neurological complications, whether Reye's disease, postinfluenzal encephalomyelitis, or encephalitis, do seem to change with these antigenic shifts. The Asian influenza of 1957, a reassortment of duck and human segments, appeared to cause higher rates of neurological complications, although no specific syndrome predominated (Johnson, 1996).

\section{Entry of virus into new host or environment}

Most emerging infections represent penetration of an agent across previous host barriers or into a new geographic area. The most dramatic example is the spread of a primate lentivirus into humans, the evolution of HIV, and then the devastating worldwide spread among humans by sexual contacts and the use of unsterile needles. Bovine spongiform encephalopathy is a prion disease in which there was unforeseen contamination of the food chain; the recycling of cattle carcasses via the rendering process amplified the infections to cause an epidemic of hundreds of thousands of cattle with ultimate transmission to humans.

Some viruses emerge from human trespasses into the natural habitat of the virus. Guanarito virus appeared among agricultural workers in central Venezuela. Primary forests had been cleared for farming, which put workers in contact with the excreta of rodents that harbored the arenavirus (Salas et al, 1991). The unidentified natural hosts of Ebola virus appear to live in the African forests. Humans infected in the forests return to their villages, where this virus can spread to other humans by contact with blood, secretions, and semen.

During the past 5 years, two fascinating dramas of emerging viruses have been played out in the United States with the invasion of West Nile virus and in Southeast Asia with Nipah virus crossing species barriers and causing epidemic human disease.

\section{West Nile virus encephalitis in the United States}

On August 23, 1999, a physician called the New York City Department of Health to report two patients with 
apparent neurological infections with severe weakness. She reported two similar cases later in the week, and at week's end an investigation of hospital records uncovered eight cases of encephalitis living in a $4 \times 4$-mile area of North Queens. The patients were from 58 to 87 years of age. No common exposure could be found, and no illnesses in the households were reported. All, however, had spent evening hours outdoors in activities such as gardening or smoking on the porch. These features suggested a mosquitoborne virus, and mosquito larvae were found in open containers, old tires, and a partially drained swimming pool in the neighborhood (Fine and Layton, 2001). On the basis of preliminary serology, a diagnosis was made of St Louis encephalitis virus infection, a virus previously unknown in New York City. On September 2, the city began mosquito control-a remarkably quick response.

In a seemingly unrelated incident in earlier August, bird deaths, particularly crows, had been reported in the Bronx, and a number of exotic birds died in the Bronx zoo. Pathological studies showed encephalitis (Steele et al, 2000). Virus was recovered and subsequently identified as West Nile virus, a virus never before recovered from natural infections in the Western Hemisphere. Reevaluation of the human cases established that they, too, were due to West Nile virus. Reexamination of sera from patients with encephalitis over the prior 3 years showed no evidence of West Nile virus-specific antibody, indicating that the virus had not been circulating unrecognized in previous years (Gubler et al, 2000). West Nile probably had been imported into the United States in 1999.

By the end of mosquito season, 62 illness had been related to West Nile virus, including 7 fatal cases of encephalitis. Subsequent serosurveys in the Queens showed that less than $1 \%$ of those infected with West Nile virus developed encephalitis (Mostashari et al, 2001). The virus was found in a variety of species of mosquitos, but Culex pipiens appeared to be the prime vector; a variety of infected birds and mammals were found in New York, New Jersey, and Connecticut. A solitary dead infected crow turned up on a main street in Baltimore.

The sequences of the recovered viruses indicate a single origin with closest similarity to a 1998 isolate from a goose in Israel (Lanciotti et al, 1999). How the virus traveled to New York is unknown; but a human, bird, and mosquito vector has been posited. A viremic traveler is unlikely, because human viremia is brief and of low level. Intentional introduction by a bioterrorist is even less probable, because the likelihood of the virus becoming established and overwintering was remote. A bird may have carried the virus across the Atlantic. Few migratory pathways cross the ocean, but storms occasionally blow birds across, and some birds, particularly pigeons, a known host, hitch rides on freighters. Smuggling of birds is common, and a viremic bird from the Middle East may well have entered in a tourist's purse. The most likely vector is a mosquito. Mosquitoes often ride on intercontinental flights in the overhead bins, and a single persistently infected mosquito landing at Kennedy Airport and taking a blood meal from a local bird may have begun the drama.

In September 1999, a prominent question was, "Could the virus overwinter?" As cold weather arrived and mosquito activity ceased, a hunt for dormant mosquitos began in the New York sewers, subways, and abandoned buildings. In midwinter, West Nile virus was recovered from a pool of mosquitos found on the walls of old Fort Totten (Nasci et al, 2001). Strangely, in February, virus was recovered from a red-tailed hawk in Westchester County; this was long after mosquito activity and raised the novel idea of prey to predator transmission (Garmendia et al, 2000). Whatever the mechanism, West Nile virus successfully overwintered in the inhospitable New York climate.

In 2000, the outbreak began in Staten Island, but by fall only 21 patients in the three initial states had developed encephalitis with only 2 deaths (Centers for Disease Control and Prevention [CDC], 2000). Although the morbidity had diminished, monitoring of mosquito and bird populations showed that the virus had spread over 12 East Coast states from North Carolina to New Hampshire. In 2001, the first case of encephalitis was in Georgia, and the woman died. By the end of the season, 64 cases of meningitis and encephalitis were reported, with the largest numbers in Florida, New Jersey, and New York; 9 patients died. The virus was found in 27 states and the District of Columbia; it was found in Canada and the Cayman Islands and crossed the Mississippi River. Fatal encephalitis in horses occurred over a large area, and an equine vaccine was granted conditional liscensure. Crows remained the major sentinel animal, with their deaths heralding the virus spread. Over 80 species of birds and 27 species of mosquitos had tested positive for West Nile virus (CDC, 2002a).

In 2002, the first human cases were reported in Louisiana on the leading edge of the spread, and they ominously occurred early in the summer. This portended a major epidemic year. The virus spread to the Continental Divide and beyond. By October, 16 over 3000 cases of West Nile virus infection were reported in the United States with 153 deaths. Human disease was reported from 39 states with Illinois, Michigan, Ohio, and Louisiana being hardest hit. Three provinces of Canada had reported 96 cases of encephalitis with one death. Over 6000 infections of horses also were reported (CDC, 2002b).

Despite the lack of virus activity in California detected by mosquito and bird monitoring, a woman residing near Los Angeles airport developed West Nile virus encephalitis, presumably from an errant mosquito coming in by air or truck. In September, 2002, a dead raven in Washington state proved positive, completing the natural spread from coast to coast in just over 3 years. An odd footnote to this 2002 
pandemic related several infections to organ transplantations and blood transfusions and a putative transmission by breast feeding (CDC, 2002b).

\section{Clinical disease and pathology}

The human incubation period is 2 to 14 days. One in five persons infected develop a mild febrile illness with malaise, headache, and lymphadenopathy, and about half of these have a roseolar or maculopapular rash. About 1 in 150 of those infected develop meningitis or encephalitis, and these neurological complications are more frequent and severe in persons over 50 years of age.

With neurological involvement, severe muscle weakness is common and was a feature that called attention to the index cases in Queens. It also has been a predictor of fatal outcome (Nash et al, 2001). In some cases, symmetrical flaccid paralysis with areflexia has led to the diagnosis of Guillian-Barré syndrome (acute demyelinating polyneuritis). Recent reports of marked asymmetry or segmental distribution of flaccid paralysis and careful electrodiagnostic studies have localized the disorder to anterior horn cell disease similar to paralytic poliomyelitis (CDC, 2002b; Leis et al, 2002; Glass et al, 2002). Similar flaccid paralysis has been noted with human infections with a related virus, Japanese encephalitis virus, and with tick-borne flaviviruses (Johnson, 1990).

Acute pancreatitis and hepatitis have been described in fatal cases of West Nile infections in Africa. In US cases, abnormalities have been restricted to the nervous system. In fatal cases, the brain may be swollen and congested, but herniation is rare. Macroscopic examination of the brain shows classic signs of encephalitis, with perivascular mononuclear cell inflammation, microglial nodules, neuronal necrosis, and neuronophagia. Infiltration of inflammatory cells in the cranial roots are described, but autopsy descriptions of spinal cord and peripheral nerves are lacking. Viral antigen is seen primarily in neurons (Shieh et al, 2000).

\section{Changes in virulence}

West Nile virus was first recovered in 1937 from the blood of a febrile woman in the West Nile province of Uganda. The initial report described the virus as "neurotropic" because of its properties in mice, not because of any neurological disease in humans (Smithburn et al, 1940). The virus was subsequently recovered in Sudan and Egypt from the blood of febrile children with dengue-like illnesses (Melnick et al, 1951), and the natural cycle of birds and mosquitos was established with humans as a dead end host (Work et al, 1955). In the early 1950s, epidemics occurred in Israel, and the association of fever with viremia and demonstrations of antibody responses convincingly linked West Nile virus with febrile illnesses (Marberg et al, 1956). In these epidemics, a few patients had headache, nuchal rigidity, and a pleocytosis relating the virus to benign meningitis, but no cases of encephalitis were recorded.

Ironically, the first documentation of human encephalitis caused by West Nile virus was in New York City in 1952. At the Sloan-Kettering Institute, 95 debilitated patients with advanced cancer were inoculated with an Egyptian strain on the premise that this benign virus might have an oncolytic effect. Nine of these patients developed encephalitis, virus was recovered from the spinal fluid of three, and an autopsy on one showed classical encephalitis (Southern and Moore, 1954).

In the 1960s, small numbers of patients with encephalitis were reported in Israel, India, and Southern Europe (Pruznaski and Altman, 1962; George et al, 1984; Hubalek and Halouzka, 1999). In 1994 in Algeria, an outbreak with 50 illnesses included 20 cases of encephalitis with 8 fatalities; this appears to present a change in epidemiology and neurovirulence (Le Guenno et al, 1996). In 1996, the first large epidemic of West Nile virus encephalitis occurred. That summer in Bucharest, Romania, over 800 patients were admitted to hospitals with central nervous system infections; $80 \%$ were confirmed as West Nile virus infections and $10 \%$ of patients died (Tsai et al, 1998). In 1999, a similar epidemic occurred in Volgograd, Russia, with over 800 patients and 40 deaths (Platonov et al, 2001). A recent outbreak in Israel in 2000 showed more severe disease, a higher rate of nervous system involvement, and higher morbidity in the elderly than in prior epidemics (Chowers et al, 2001). Although reports from Central Africa report the emergence of hepatotropic strains causing a yellow fever-like illnesses (Georges et al, 1987), in the Middle East, Eastern Europe, and the United States, the appearance of epidemic encephalitis suggests the evolution of more neurovirulent strains of West Nile virus (Johnson and Irani, 2002).

\section{Nipah virus encephalitis}

On September 29, 1998, cases of encephalitis were reported near Ipoh, Malaysia, primarily among pig farmers and their families. The initial speculation was that encephalitis was due to Japanese encephalitis virus, an arbovirus endemic in the area and known to infect piglets as an important amplifying host. Several epidemiological features, however, caused this conclusion to be suspect: (1) The patients were primarily adults, whereas children usually predominate in Japanese encephalitis outbreaks. (2) Household clusters of disease were seen, which is rare with arboviral infections. (3) A high percentage of patients had contact with pigs, and many of the pigs were ill with respiratory disease; Japanese encephalitis virus does not cause clinical disease in pigs, and humans with encephalitis usually do not report direct contact with swine. (4) A number of the patients had been immunized with Japanese encephalitis virus vaccine. 
Despite these questions, spraying and other methods of mosquito control were initiated.

In February, similar disease in pigs and humans appeared in two other sites further to the south, and this followed the transport of large numbers of pigs from Ipoh (CDC, 1999a, 1999b). In March, a small but informative outbreak occurred in Singapore. Singapore has no pig farms and only two abattoirs; the outbreak involved 11 employees of one of the abattoirs, all of whom had direct contact with pigs or their viscera. No other employees, no family members, and no medical personnel caring for the patients developed disease. This established the transmission from pigs and the lack of human to human transmission (Lee et al, 1999). The outbreak in Singapore ended when the abattoirs were closed, and importation of pigs from Malaysia was prohibited. The outbreaks in Malaysia ceased in April, but only after 1 million pigs had been culled from the outbreak zones and surrounding area and all internal transportation of pigs was banned. By April, 265 cases of encephalitis, including 105 deaths, had been associated with the outbreaks in Malaysia (Chua et al, 2000a).

In March 1999, a virus was recovered from spinal fluid of three fatal human cases (Chua et al, 1999). This proved to be a newly recognized virus with characteristics of the family Paramyxoviridae. These viruses are not arthropod-borne but are spread by respiratory routes. The virus was in the respiratory tracts of pigs, and antibodies were found convalescent human sera and in the sera of swine, dogs, cats, horses, and bats.

\section{Clinical disease and pathology}

The incubation period appears to be about 2 weeks, with over $90 \%$ of patients giving a history of contact with pigs at that time. Patients present with fever, headache, dizziness, vomiting, and reduced consciousness. The distinctive features were the focal clinical signs, with segmental myoclonus, cerebellar ataxia, and prominent signs of brainstem and cervical cord involvement. The spinal fluid was striking with cell counts up to 1000 and protein contents up to $400 \mathrm{mg} \%$ (Goh et al, 2000; Li et al, 1999). The most characteristic finding, however, was the magnetic resonance imaging that showed multiple, small (less the $2 \mathrm{~cm}$ ), high signal densities within the white matter on T-2 weighted images (Lim et al, 2002).

About one third of patients had an ingravescent course to death. Recovery of virus from spinal fluid was associated with high mortality (Chua et al, 2000b). Autopsy studies showed a widespread vasculitis, with the central nervous system being most severely affected. Small vessels were often occluded, giving multiple areas of infarction. Endothelial syncytial formation was sometimes observed. Intranuclear and cytoplasmic inclusions were seen in endothelial cells and neurons, indicating both a direct neuronal infection and an endothelial infections giving rise to vascular occlusions and infarc- tions (Wong, 2000). Viral antigen was prominent in neurons.

Another unique feature of this encephalitis is its tendency to relapse. In a 2-year follow-up after the 1998-1999 outbreaks, $7.5 \%$ of patients who had recovered from encephalitis had had a relapse, with acute onset of fever and signs of encephalitis; $3.4 \%$ of patients who had been infected but had not had encephalitis developed signs of encephalitis. Four of the patients who developed recurrent or late onset encephalitis died, and autopsies on two showed changes of focal encephalitis and virus antigen in brain. Perivenular demyelination characteristic of postinfectious encephalomyelitis was not seen (Tan et al, 2002).

\section{Nature and origins of Nipah virus}

Studies of antigenicity and sequences of Nipah virus show it is closely relate to Hendra virus and only distantly related to measles and other paramyxoviruses (Harcourt et al, 2000). Nipah and Hendra viruses now comprise a new genus of paramyxoviruses.

Hendra virus was first recognized in Queensland, Australia, in 1994 after an outbreak of respiratory disease in race horses and their human handlers; 14 horses and one trainer died (Murray et al, 1995). In an independent episode over $1000 \mathrm{~km}$ north, two horses and a farmer died; but in this instance the farmer initially had only a brief meningitic illness and then 13 months later developed fatal encephalitis (O'Sullivan et al, 1997).

Hendra virus has a wide host range on experimental infection, but seroepidemiological studies have suggested that the natural host is the large fruit bat (flying fox). Acting on this foreknowledge about Hendra virus, Nipah was promptly shown to infect fruit bats. Indeed, at the farm associated with the index cases, the pig pens are only partially roofed and fruit trees overhang the open areas of the pens. Fruit bats in these trees drop partially eaten fruit, which was scavenged by the pigs; the bats also urinated on the pigs. Nipah virus has been recovered from the saliva on partially eaten fruit and from urine of the Island flying foxes (Chua et al, 2002).

Emergence of Nipah encephalitis appears to have occurred with crossing of two species barriers by saliva or urine from bats to pigs and by respiratory route from pigs to humans. Similar breaching of species barriers are likely to explain other explosive outbreaks of human encephalitis, such as the one that caused panic in Siliguri, North Bengal, in February 2001 (Haldar et al, 2001).

\section{Discussion}

In the Institute of Medicine report on emerging infectious diseases, six factors were identified that shape emergence: human demographics and behavior, technology and industry, economic development 
and land use, international travel and commerce, microbial adaptation and change, and breakdown of public health measures (Lederberg et al, 1992). Most of these depend on human activities. The burgeoning population provides a greater pool for viral mutations, a larger population to provide susceptibles, and greater interaction with natural viral habitats. Increased speed and scope of movement of humans also are major factors; 150 years ago a round the world trip took a year, now we can circle the globe in 24 hours. Every viral infection in the world can be in your living room within one incubation period. The amount of human traveling is staggering; more than 500 million persons cross international boundaries on commercial aircraft each year, about 70 million work legally or illegally in other countries, and 50 million are refugees or displaced persons (Wilson, 1995). The opportunity to transport infectious agents or their vectors increases every year.

Since emerging infections are often related to human activities, some have implied that they have arisen from human wickedness. The spread of HIV and type 2 herpes simplex virus with greater sexual licence, the spread of zoonotic agents with deforestation, and the epidemic of bovine spongiform encephalopathy by the unnatural feeding of bovine meat and bone meal to calves have strengthened this judgmental position. Unfortunately this leads to the assumption that emerging diseases can be prevented by political or environmental "correctness." In fact, many good and generous activities can be exploited by viruses (Table 2). Day care and early schooling of children have enhanced the spread of enteroviruses and facilitated early exposure to measles and other diseases. Travel and recreational activities have increased exposure to rabies, arboviruses, and other zoonotic infections. Irrigation in California and

\section{References}

Centers for Disease Control and Prevention (1999a). Outbreak of Hendra-like virus-Malaysia and Singapore, 1998-1999. Morb Mort Wkly Rep 48: 265-269.

Centers for Disease Control and Prevention (1999b). Update: outbreak of Nipah virus-Malaysia and Singapore, 1999. Morb Mort Wkly Rep 48: 335-337.

Centers for Disease Control and Prevention (2000). Update: West Nile virus activity-Eastern United States, 2000. Morb Mort Wkly Rep 49: 1044-1047.

Centers for Disease Control and Prevention (2002a). West Nile virus activity-United States, 2001. Morb Mort Wkly Rep 51: 497-501.

Centers for Disease Control and Prevention (2002b). West Nile virus activity-United States, October 10-16, 2002, and update on West Nile virus infections in recipients of blood transfusions, 2002. Morb Mort Wkly Rep 51: 929-931.

Chowers MY, Lang R, Nassar F, Ben-David D, Giladi M, Rubinshtein E, Itzhaki A, Mishal J, Siegman-Igra Y,
Table 2 Societal changes that enhance the evolution and spread of neurotropic viruses

Providing larger pool Increasing population

of susceptibles Increasing speed and amount of travel

Altering human or

animal contacts

Societal mores Increased sexual partner numbers

Day care with early exposure

Altering woods for suburbs and recreation Agricultural clearing or irrigation

Global movement of animals and animal products

Medical practices Blood transfusions

Immunosuppressive therapy

Organ transplants (infected donor)

Antiviral drugs (encourage resistance)

Modified from Johnson (1998).

Africa have enhanced standards of living and epidemics of arboviral diseases. The new planning of suburban housing to preserve old deciduas trees, instead of land clearing with new planting, has brought the habitat of the tree-hole mosquito, the vector of La Crosse viruses, into the yards where susceptible children play (Johnson et al, 1968). International commerce has enhanced wealth and medical procedures have enhanced health, but both have been associated with unexpected transmissions of microbes. In recent years, Creutzfeldt-Jakob disease, rabies, HIV, and West Nile virus have all been transmitted with transplanted tissues.

Greater international monitoring of "new" viruses, more investigations of the ecology of viruses, and deeper understanding of basic viral and host factors are needed to prepare for future outbreaks. We also must acknowledge that as we alter our common habitat, new viruses will evolve genetically or old viruses will change hosts and habitats to exploit these changes.

Kitzes R, Pick N, Landau Z, Wolf D, Bin H, Mendelson E, Pitlik SD, Weinberger M (2001). Clinical characteristics of the West Nile fever outbreak, Israel, 2000. Emerg Infect Dis 7: 675-678.

Chua KB, Bellini WJ, Rota PA, Harcourt BH, Tamin A, Lam SK, Ksiazek TG, Rollin PE, Zaki SR, Shieh W-J, Goldsmith CS, Gubler DJ, Roehrig JT, Eaton B, Gould AR, Olson J, Field H, Daniels P, Ling AE, Peters CJ, Anderson LJ, Mahy BW (2000a). Nipah virus: a recently emergent deadly paramyxovirus. Science 288: 14321435.

Chua KB, Goh KJ, Wong KT, Kamarulzaman A, Tan PS, Ksiazek TG, Zaki SR, Paul G, Lam SK, Tan CT (1999). Fatal encephalitis due to Nipah virus among pig-farmers in Malaysia. Lancet 354: 1257-1259.

Chua KB, Koh CL, Hooi PS, Wee KF, Khong JH, Chua BH, Chan YP, Lim ME, Lam SK (2002). Isolation of Nipah virus from Malaysian Island flying-foxes. Microbes Infect 4: 145-151. 
Chua KB, Lam SK, Tan CT, Hooi PS, Goh KJ, Chew NK, Tan KS, Kamarulzaman A, Wong KT (2000b). High mortality in Nipah encephalitis is associated with presence of virus in cerebrospinal fluid. Ann Neurol 48: 802-805.

Chumakov M, Voroshilova M, Shindarov L, Lavrova I, Gracheva L, Koroleva G, Vasilenko S, Brodvarova I, Nikolova M, Gyurova S, Gacheva M, Mitov G, Ninov N, Tsylka E, Robinson I, Frolova M, Bashkirtsev V, Martiyanova L, Rodin V. (1979). Enterovirus 71 isolated from cases of epidemic poliomyelitis-like disease in Bulgaria. Arch Virol 71: 329-340.

Fine A, Layton M (2001). Lessons from the West Nile viral encephalitis outbreak in New York City, 1999: implications for bioterrorism preparedness. Clin Infect Dis 32: 277-282.

Garmendia AE, Van Kruiningen HJ, French RA, Anderson JF, Andreadis TG, Kumar A, West AB (2000). Recovery and identification of West Nile virus from a hawk in winter. J Clin Microbiol 38: 3110-3111.

Georges AJ, Lesbordes JL, Georges-Courbot MC, Meunier DMY, Gonzalez JP (1987). Fatal hepatitis from West Nile virus. Ann Inst Pateur/Virol 138: 237-244.

George S, Gourie-Devi M, Rao JA, Prasad SR, Pavri KM (1984). Isolation of West Nile virus from the brains of children who had died of encephalitis. Bull World Health Org 62: 879-882.

Glass JD, Samuels O, Rich MD (2002) Poliomyelitis due to West Nile virus. N Engl J Med 347: 1280-1281.

Goh KJ, Tan CT, Chew NK, Tan PS, Kamarulzaman A, Sarji SA, Wong KT, Abdullah BJ, Chua KB, Lam SK (2000). Clinical features of Nipah virus encephalitis among pig farmers in Malaysia. N Engl J Med 342: 1229-1235.

Gubler DJ, Campbell GL, Nasci R, Komar N, Petersen L, Roehrig JT (2000). West Nile virus in the United States: guidelines for detection, prevention, and control. Viral Immunol 13: 469-475.

Le Guenno B, Bougermouh A, Azzam T, Bouakaz R (1996). West Nile: a deadly virus? Lancet 348: 1315.

Haldar NR, Dasgupta K, Khandelwal AK, Haldar N, Banerjee S, Das S, Chakraborty S (2001). First epidemic of viral encephalitis in 2001 of highly infectious nature with fading mortality at Siliguri. J Neurol Sci 187(Suppl 1): S121.

Harcourt BH, Tamin A, Ksiazek TG, Rollin PE, Anderson LJ, Bellini WJ, Rota PA (2000). Molecular characterization of Nipah virus, a newly emergent Paramyxovirus. Virology 271: 334-349.

Hashimoto I, Hagiwara A (1983). Comparative studies on the neurovirulence of temperature-sensitive and temperature-resistant viruses of enterovirus 71 in monkeys. Acta Neuropathol 60: 266-270.

Ho M, Chen E-R, Hsu K-H, Twu S-J, Chen K-T, Tsai S-F, Wang J-R, Shih S-R (1999). An epidemic of enterovirus 71 infection in Taiwan. N Engl J Med 341: 9-935.

Huang CC, Liu CC, Chang YC, Chen CY, Wang ST, Yeh TF (1999). Neurologic complications in children with enterovirus 71 infection. N Engl J Med 341: 936-942.

Hubalek Z, Halouzka J (1999). West Nile fever-a reemerging mosquito-borne viral disease in Europe. Emerg Infect Dis 5: 643-650.

Johnson KP, Lepow ML, Johnson RT (1968). California encephalitis. I. Clinical and epidemiological studies. Neurology 18: 250-254.

Johnson RT (1990). Arboviral encephalitis. In: Tropical and geographical medicine. Warren KS, Mahmoud AAF (eds). New York: McGraw-Hill, pp 691-699.
Johnson RT (1994). Emerging infections of the nervous system. J Neurol Sci 124: 3-14.

Johnson RT (1996). Emerging viral infections. Arch Neurol 53: $18-22$.

Johnson RT (1998). Viral infections of the nervous system, 2nd ed. Philadelphia: Raven-Lippincott.

Johnson RT, Irani DN (2002). West Nile virus encephalitis in the United States. Curr Neurol Neurosci Rep 2: 496500.

Kono R, Sasagawa A, Kodama H, Uchida N, Akao Y, Mukoyama J, Fujiwara T (1973). Neurovirulence of acute-haemorrhagic-conjunctivitis virus in monkeys. Lancet 13: 61-63.

Lanciotti RS, Roehrig JT, Deubel V, Smith J, Parker M, Steele K, Crise B, Volpe KE, Crabtree MB, Scherret JH, Hall RA, MacKenzie JS, Cropp CB, Panigrahy B, Ostlund E, Schmitt B, Malkinson M, Banet C, Weissman J, Komar N, Savage HM, Stone W, McNamara T, Gubler DJ (1999). Origin of the West Nile virus responsible for an outbreak of encephalitis in the northeastern United States. Science 286: 2333-2337.

Lederberg J, Shope RE, Oaks SC (1992). Emerging infection: microbial threats to health in the United States. Washington DC: National Academy Press.

Lee KE, Umapathi T, Tan CB, Tjia HT, Chua TS, Oh HM, Fock KM, Kurup A, Das A, Tan AK, Lee WL (1999). The neurological manifestations of Nipah virus encephalitis, a novel paramyxovirus. Ann Neurol 46: 428-432.

Leis AA, Stokic DS, Polk JL, Dostrow V, Winkelmann M (2002). A poliomyelitis-like syndrome from West Nile infection. N Engl J Med 347: 1279-1280.

Li HC, Fujiyoshi T, Lou H, Yashiki S, Sonoda S, Cartier L, Nunez L, Munoz I, Horai S, Tajima K. (1999). The presence of ancient human T-cell lymphotropic type I provirus DNA in an Andean mummy. Nat Med 5: 14281432.

Lim CC, Lee KE, Lee WL, Tambyah PA, Lee CC, Sitoh YY, Auchus AP, Lin BK, Hui F (2002). Nipah virus encephalitis: serial MR study of an emerging disease. Radiology 222: 219-226.

Lum LC, Wong KT, Lam SK, Chua KB, Goh AY, Lim WL, Ong BB, Paul G, AbuBakar S, Lambert M (1998). Fatal enterovirus 71 encephalomyelitis. J Pediatr 133: 795798.

Marberg K, Goldblum N, Sterk VV, Jasinska-Klingberg W, Klingberg MA (1956). The natural history of West Nile fever: clinical observations during an epidemic in Israel. Am J Hyg 64: 259-269.

Melnick JL, Paul JR, Riordan JT, Barnett VH, Goldblum N, Zabin E (1951). Isolation from human sera in Egypt of a virus apparently identical to West Nile virus. Proc Soc Exp Biol Med 77: 661-665.

Mostashari F, Bunning ML, Kitsutani PT, Singer DA, Nash D, Cooper MJ, Katz N, Liljebjelke KA, Biggerstaff BJ, Fine AD, Layton MC, Mullin SM, Johnson AJ, Martin DA, Hayes EB, Campbell GL (2001). Epidemic West Nile encephalitis, New York, 1999: results of a householdbased seroepidemiological survey. Lancet 358: 261264.

Murray K, Selleck P, Hooper P, Hyatt A, Gould A, Gleeson L, Westbury H, Hiley L, Selvey L, Rodwell B, Ketterer $P$ (1995). A morbillivirus that caused fatal disease in horses and humans. Science 268: 94-97.

Nasci RS, Savage HM, White DJ, Miller JR, Cropp BC, Godsey MS, Kerst AJ, Bennett P, Gottfried K, Lanciotti RS (2001). West Nile virus in overwintering 
Culex mosquitoes, New York City, 2000. Emerg Infect Dis 7: 742-744.

Nash D, Mostashari F, Fine A, Miller J, O’Leary D, Murray K, Huang A, Rosenberg A, Greenberg A, Sherman M, Wong S, Layton M (2001). The outbreak of West Nile virus infection in the New York City area in 1999. $N$ Engl J Med 344: 1807-1814.

O’Sullivan JD, Allworth AM, Paterson DL, Snow TM, Boots R, Gleeson LJ, Gould AR, Hyatt AD, Bradfield J (1997). Fatal encephalitis due to novel paramyxovirus transmitted from horses. Lancet 349: 93-95.

Platonov AE, Shipulin GA, Shipulina OY, Tyutyunnik EN, Frolochkina TI, Lanciotti RS, Yazyshina S, Platonova OV, Obukhov IL, Zhukov AN, Vengerov YY, Pokrovskii VI (2001). Outbreak of West Nile virus infection, Volgograd Region, Russia, 1999. Emerg Infect Dis 7: 128132.

Pruzanski W, Altman R (1962). Encephalitis due to West Nile fever virus. World Neurol 3: 524-527.

Salas R, de Manzione N, Tesh RB, Rico-Hesse R, Shope RE, Betancourt A, Godoy O, Bruzual R, Pacheco ME, Ramos B, Taibo ME, Tamayo JG, Jaimes E, Vasquez C, Araoz F, Querales J (1991). Venezuelan haemorrhagic fever. Lancet 338: 1033-1036.

Shieh WJ, Guarner J, Layton M, Fine A, Miller J, Nash D, Campbell GL, Roehrig JT, Gubler DJ, Zaki SR (2000). The role of pathology in an investigation of an outbreak of West Nile encephalitis in New York, 1999. Emerg Infect Dis 6: $370-372$.

Smithburn KC, Hughes TP, Burke AW, Paul JH (1940). A neurotropic virus isolated from the blood a native of Uganda. Am J Trop Med Hyg 20: 471-492.
Southam CM, Moore AE (1954). Induced virus infections in man by the Egypt isolates of West Nile virus. Am J Trop Med Hyg 3: 19-50.

Steele KE, Linn MJ, Schoepp RJ, Komar N, Geisbert TW, Manduca RM, Calle PP, Raphael BL, Clippinger TL, Larsen T, Smith J, Lanciotti RS, Panella NA, McNamara TS (2000). Pathology of fatal West Nile virus infections in native and exotic birds during the 1999 outbreak in New York City, New York. Vet Pathol 37: 208-224.

Tan CT, Goh KJ, Wong KT, Sarji SA, Chua KB, Chew NK, Murugasu P, Loh YL, Chong HT, Tan KS, Thayaparan T, Kumar S, Jusoh MR (2002). Relapsed and late-onset Nipah encephalitis. Ann Neurol 51: 703-708.

Tsai TF, Popovici F, Cernescu C, Campbell GL, Nedelcu NI (1998). West Nile encephalitis epidemic in southeastern Romania. Lancet 352: 767-771.

Wadia NH, Katrak SM, Misra VP, Wadia PN, Miyamura K, Hashimoto K, Ogino T, Hikiji T, Kono R (1983). Poliolike motor paralysis associated with acute hemorrhagic conjunctivitis in an outbreak in 1981 in Bombay, India: clinical and serologic studies. J Infect Dis 147: 660668.

Wilson ME (1995). Travel and the emergence of infectious diseases. Emerg Infect Dis 1: 39-46.

Wong KT (2000). Emerging and re-emerging epidemic encephalitis: a tale of two viruses. Neuropathol Appl Neurobiol 26: $313-318$.

Work TH, Hurlbut HS, Taylor RM (1955). Indigenous wild birds of the Nile delta as potential West Nile virus circulating reservoirs. Am J Trop Med Hyg 4: 872-888.

Yin-Murphy M (1984). Acute hemorrhagic conjunctivitis. Prog Med Virol 29: 23-44. 